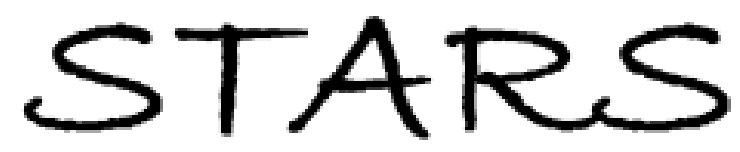

University of Central Florida

STARS

Faculty Bibliography 2010s

Faculty Bibliography

$1-1-2010$

\title{
Theory and Practice of Education
}

Karen L. Biraimah

University of Central Florida

Find similar works at: https://stars.library.ucf.edu/facultybib2010

University of Central Florida Libraries http://library.ucf.edu

This Book Review is brought to you for free and open access by the Faculty Bibliography at STARS. It has been accepted for inclusion in Faculty Bibliography 2010 s by an authorized administrator of STARS. For more information, please contact STARS@ucf.edu.

\section{Recommended Citation}

Biraimah, Karen L., "Theory and Practice of Education" (2010). Faculty Bibliography 2010s. 7105.

https://stars.library.ucf.edu/facultybib2010/7105

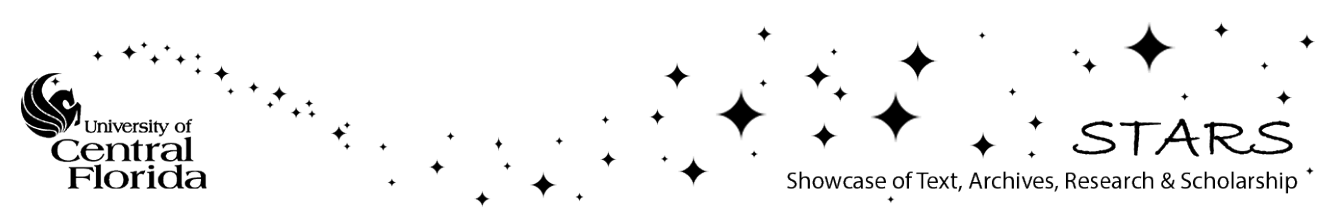


and are influenced by wider trends. The many tensions arising from these trends and the increasing attempts to reach more and more children often at younger and younger ages raise challenges and questions that families, civil society, government, and others (including the private sector) continue to wrestle with today.

Inclusion of the New Zealand case is especially welcome, given the abundance of previously published studies comparing the United States and other Western European countries such as France, Sweden, and the United Kingdom. This is of particular importance given New Zealand's serious efforts to address the role of cultural diversity, including bicultural early learning approaches for Aboriginal communities. The contrast between New Zealand's approaches to early education for diverse populations and those discussed in the chapters on France, Germany, Sweden, or the United States is worth much more reflection and debate. However, while there may be less cultural diversity to manage in Japan than in the countries listed above, the combination of an increasing percentage of elderly citizens, low numbers of young children, and growing demand by women for child care poses significant challenges for the Japanese government.

The discussion across the chapters as to how services are provided, monitored, and funded is useful, given the variation across countries and the considerable debates surrounding these topics. However, the choices and decisions around who provides early childhood services-mainly government (France), largely nonstate (Japan), or a mix (United States) — and how these have been made over time could be contrasted even more sharply with information about how well these same services are delivered to the most vulnerable, marginalized, or at-risk children. This last point links to the issue discussed in most of the chapters regarding the importance of creating effective links or continuity of provision between children's homes (and families), the early learning centers, and the primary school.

There are many other valuable issues and questions raised throughout this volume. The authors enrich greatly the debate and discourse in the area of early schooling in different country contexts-in large part because they have chosen to acknowledge the different choices made over time by countries and communities. They repeatedly come back to the fundamental link and interaction between policies (and the programs that emerge from them) and the broader (and increasingly diverse) cultural expectations toward children.

KATHY BARTLETT

Aga Khan Foundation

Theory and Practice of Education by David A. Turner. London: Continuum Publishing Group, 2007. 172 pp. \$144.00 (cloth). ISBN 0-8264-9107-3.

David A. Turner's Theory and Practice of Education provides scholars with a thoughtprovoking argument that challenges traditional perspectives regarding linkages between policy and research. Turner also offers his readers what he considers to be a more effective model for informing this process while developing a well- 
structured, although general, critique of current research paradigms. Building on "an explosion of interest in 'evidence-based policy" (153), Turner implores researchers to produce evidence that is valuable to policy makers in an era of policybased research. To this end, he introduces readers to the multicentered research model that, in his opinion, is superior to current single-centered models.

While Turner's work can enrich current research models, it also has its limitations. Clearly, this is a thoughtful book that encourages the reader to reflect on the effectiveness of current research paradigms, yet it is not designed to serve as a standard classroom textbook, which traditionally might include systematic guidelines for identifying and categorizing key educational problems, theories, and research models. Moreover, omitted from this work is a clear linkage between his theoretical arguments and more specific educational issues of interest to comparativists, although his broad-based analysis of educational challenges (such as equity) helps clarify the perceived effectiveness of single- and multicentered research models. While this book does not meet expectations as a classroom reference tool, it is a rich resource for focused classroom discussion and debate.

What Theory and Practice of Education does accomplish, however, is to carefully delineate a succinct argument for strengthening linkages between evidence-based policy and policy-based research through the development of more effective research models. Building on this concept, Turner begins with a general critique of single-centered research, suggesting that the plethora of current educational problems demands the identification of better data and evidence and that this can only be achieved through the multicentered research model. To this end, Turner coopts Einstein's idea that research models should be as simple as possible but no simpler. Following this maxim, Turner argues that current single-centered research is too simple and cannot produce the quality of evidence needed to inform education policy. He then asks scholars to pay closer attention to multicentered research models, particularly those incorporating game and complexity theory. Turner then defends the multicentered approach to research, which he sees as superior to single-centered approaches that are, in his opinion, plagued with overgeneralizations regarding homogeneous groups. For Turner, a new perspective on educational issues provided by multicentered research is necessary to inform current educational agendas. Simply put, he believes educational researchers and policy makers should accept the reality that homogeneous groups, when exposed to the same influences and environmental factors, can select different outcomes. Turner believes that this revision in research perspective can only be facilitated by multicentered research. In fairness to the vibrant array of single-centered research models, however, it is important to add that Turner's relentless critique of these models remains generic in nature and does not underscore particular weaknesses in specific models, which can be both sophisticated and dynamic. If he had extended this critique, it may have strengthened his thesis regarding the need for multicentered research models.

The book also provides some general perspectives that can inform practitioners, researchers, and policy makers alike. For instance, as a seasoned teacher, I strongly agree with Turner's assertion that "everything that is really important in the educational process cannot be controlled" (30). Expanding on this theme through a lengthy discussion of Lev Vygotsky's theories, Turner provides the reader 
with multiple issues within the classroom that often challenge dominant educational policies. For example, when addressing the need to manage a classroom, we are faced with the dilemma of teachers trained to maintain order and control over students who, by their very nature, are uncontrollable. Building on Vygotsky's perspectives, Turner suggests that education is an uncontrollable process that cannot be understood through current single-centered research models that assume, erroneously, that we can both understand and control the educational process. This is certainly an interesting issue, regardless of the research model selected.

The value of Turner's text is that it not only encourages the reader to contemplate new research models but also reinforces the need to apply effective research models to a broad array of educational problems and challenges. Another strength of the book is Turner's extended argument for greater transparency in research and thus, by extension, more transparency in educational policy decisions.

In conclusion, Turner's Theory and Practice of Education provides an analysis and assessment of the potential contributions of evidence-based research, as well as a clarion call to replace inadequate single-centered thinking that has, until now, been the driving force behind evidence-based educational policy. This represents a tantalizing possibility, although the magnitude of the proposed changes to research and policy-making paradigms would be unparalleled. Thus, even if researchers follow Turner's plea to modify their methodologies, we are more likely to see adjustments to, rather than radical reform of, current educational research models. Nonetheless, regardless of the degree of future reform anticipated, Turner has certainly offered new models that can enrich the analytical tools available to educational researchers and policy makers. And finally, while this book was not necessarily written with the comparativists in mind, its perceptions regarding appropriate educational models can certainly be applied by comparativists and international researchers. For these professionals, Turner succeeds in providing challenging issues and perspectives regarding the nature of educational research and its linkage to the development of evidenced-based policy, yet, in most cases, he leaves the specialized applications to the individual reader.

KAREN L. BIRAIMAH

University of Central Florida

Democracy and Social Change: A History of South Korean Student Movements, 1980-2000 by Mi Park. Oxford: Peter Lang, 2008. 291 pp. \$64.95 (paper). ISBN 978-303911-066-7.

In Democracy and Social Change: A History of South Korean Student Movements, 1980-2000, Mi Park explores the pivotal role that student movements played in the genesis of democratic change in South Korea. The author focuses on two specific periods for comparison. The first, the 1980s, Park describes as a decade of enhanced participation in which the people, led largely by highly organized clandestine student groups, banded together against an authoritarian government to demand increased 